Psoriasis in those planning a family, pregnant or breast-feeding. The Australasian Psoriasis Collaboration

Marius Rademaker

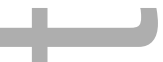

Karen Agnew

$-$

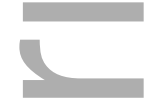

Megan Andrews

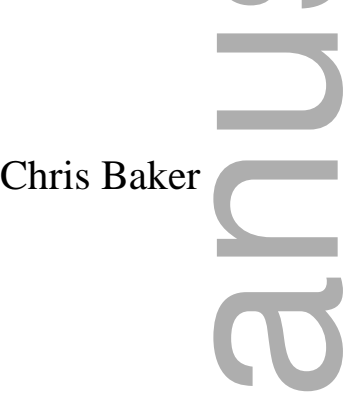

Peter Foley

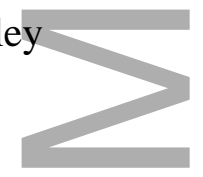

John Frew

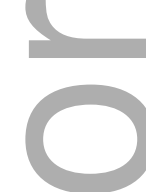

Kurt Gebauer

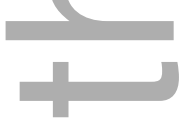

Monisha Gupta

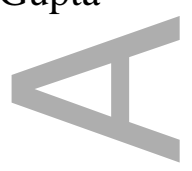

Associate Professor, Waikato Clinical Campus, Auckland Medical

School, New Zealand. marius.rademaker@gmail.com

Dermatology Department, Greenlane Clinical Centre \& Starship

Children's Hospital, Auckland, New Zealand. KAgnew@adhb.govt.nz

68 Ipswich Rd, Woolloongabba QLD 4102, Australia

meganandrews27@bigpond.com

Visiting Dermatologist, The Skin and Cancer Foundation of Victoria,

Melbourne, Australia. katherinearmour@gmail.com

Associate Professor of Dermatology, The University of Melbourne, St

Vincent's Hospital, Melbourne, and Skin \& Cancer Foundation Inc.

Melbourne, Australia. bakerc.k@bigpond.com

Associate Professor of Dermatology, The University of Melbourne, St

Vincent's Hospital, Melbourne, and Skin \& Cancer Foundation Inc.

Melbourne, Australia. Peter.Foley@svha.org.au

Dermatology Department, Prince of Wales Hospital, Randwick, NSW

2031 Sydney, Australia.jwfrew@gmail.com

Clinical Associate Professor of Dermatology University of Western

Australia. Freemantle Dermatology, 229 High Street, Freemantle,

Western Australia 6160, kurt@fremantledermatology.com.au

Senior Staff Specialist, Liverpool Hospital, Visiting Dermatologist,

The Skin Hospital, Darlinghurst, NSW, and Conjoint Senior Lecturer,

UNSW, Sydney, NSW, Australia. vinaymonisha@gmail.com

This is the author manuscript accepted for publication and has undergone full peer review but has not been through the copyediting, typesetting, pagination and proofreading process, which may lead to differences between this version and the Version of Record. Please cite this article as doi: $10.1111 /$ ajd.12641

This article is protected by copyright. All rights reserved 

Australia. Debra.Kennedy@ health.nsw.gov.au

Gillian Marshman

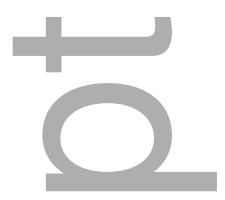

John Sullivan
Senior Visiting Dermatologist, Flinders Medical Centre and

Repatriation General Hospital, Adelaide, SA, Australia

gmderm2@senet.com.au

Holdsworth House Medical Practice, 26 College St, Sydney, NSW, Australia.John.Sullivan@holdsworthhouse.com.au

Address for correspondence: Dr John Sullivan, Holdsworth House Medical Practice, 26 College St, Sydney, NSW, Australia. John.Sullivan@holdsworthhouse.com.au, or A/Prof Marius Rademaker, Waikato Clinical Campus, Auckland Medical School, New Zealand. marius.rademaker@gmail.com

Acknowledgements: We are very grateful to AbbVie Australia (Mascot, New South Wales, Australia) for an unrestricted educational grant, which made this position statement possible. They had no influence in the topic, the discussion or the preparation of the manuscript.

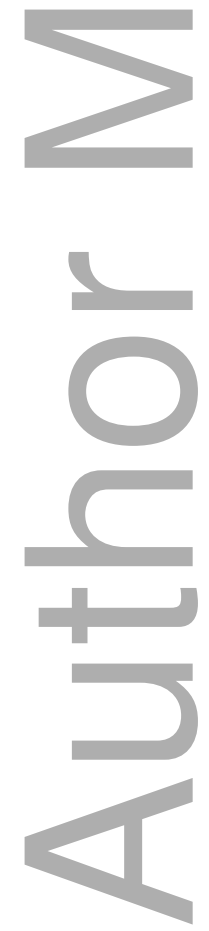


PROF. MARIUS RADEMAKER (Orcid ID : 0000-0003-3393-6748)

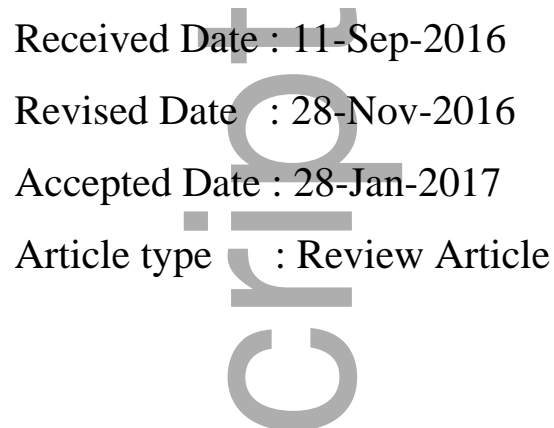

\title{
Psoriasis in those planning a family, pregnant or breast-feeding.
}

Keywords: expert opinion, pregnancy, lactation, methotrexate, acitretin, ciclosporin, corticosteroids, biologic therapy, etanercept, adalimumab, infliximab, ustekinumab, secukinumab, ixekizumab, topical therapy, teratogenicity

\begin{abstract}
The Australasian Psoriasis Collaboration (APC) has reviewed the evidence for managing moderate to severe psoriasis in those planning a family, who are pregnant or are breast-feeding.
\end{abstract}

The severity of the psoriasis, associated co-morbidities, and specific anti-psoriasis treatments, along with other exposures, can have a deleterious effect on pregnancy outcomes. Psoriasis itself increases the risk of preterm and low birth weight babies, along with spontaneous and induced abortions, but no specific birth defects have been otherwise demonstrated.

The baseline risk for a live born baby to have a major birth defect is 3\%, and significant neurodevelopmental problem is 5\%. In Australia, pregnant women with psoriasis are more likely to be overweight/obese, depressed, smoke in their first trimester, and are also less likely to take prenatal vitamins/supplements. Preconception counselling to improve maternal, pregnancy and baby health is therefore strongly encouraged.

The topical and systemic therapies commonly used in psoriasis are each discussed separately, with regards to pregnancy exposure, breast-feeding and effects on male fertility/mutagenicity. The systemic therapies included are acitretin, adalimumab, apremilast, certolizumab, 
ciclosporin, etanercept, infliximab, ixekizumab, methotrexate, nbUVB, prednisone, PUVA, secukinumab and ustekinumab. The topical therapies include anthralin/dithranol, calcipotriol, coal tar, corticosteroids (weak, potent and super-potent), moisturisers, salicylic acid, tacrolimus, and tazarotene.

As a general recommendation, effective drugs that have been widely used for years are preferable to newer alternatives with less fetal safety data. It is equally important to evaluate the risks of not treating, as severe untreated disease may negatively impact both mother and the fetus.

\section{Introduction}

There is a lack of practical guidance available to assist in the management of the important clinical scenario when a patient with psoriasis plans to have a child or, as $50 \%$ of pregnancies are unplanned, is pregnant. ${ }^{1-2}$

Much remains unknown about the inheritance and subsequent development of psoriasis. The risks of offspring developing psoriasis are $50 \%$ if both parents have psoriasis, $16 \%$ if one parent has psoriasis and is $8 \%$ if neither parent but one sibling has psoriasis. Forty percent of those with psoriasis have a first degree relative with psoriasis. ${ }^{3}$ Concordance of psoriasis in monozygotic is $70 \%$, falling to $30 \%$ in dizygotic twins. ${ }^{4}$ For reasons yet to be determined, affected men have a higher risk of transmitting psoriasis to their children. ${ }^{5,6}$

The limited evidence available suggests that psoriasis usually improves significantly during pregnancy: ${ }^{8-10} 55 \%$ improve (range $33-60 \%$ ), $25 \%$ report no change, and $25 \%$ worsen. Conversely after childbirth, psoriasis is likely to flare over the subsequent weeks: ${ }^{8-10} 65 \%$ worsen (range 40-88\%), 25\% demonstrate no change, and 10\% improve. For patients with psoriatic arthritis, $80 \%$ improve or remit during pregnancy, whilst $70 \%$ flare post partum.

Psoriasis is not known to have a significant impact on fertility, either male or female. ${ }^{8,11-13}$ However, one US study did observe significantly fewer than expected births to mothers with psoriasis. One possible explanation is avoidance of intimacy consequent to genital psoriasis causing pain, discomfort and embarrassment (in up to a third of patients). Significant scrotal disease may also lead to increased testicular temperature and reduced fertility. ${ }^{14}$ 
The data on pregnancy outcomes is conflicting. ${ }^{8,11-13}$ Some studies have suggested a possible increase in preterm and low birth weight babies along with spontaneous and induced abortions. ${ }^{13-15}$ Similar inflammatory / autoimmune diseases such as rheumatoid arthritis and inflammatory bowel disease have also been associated with low birth weight, preterm birth and spontaneous and induced abortions. This has been postulated to be due to immune dysfunction, pro-inflammatory cytokines and effects on endothelial cells resulting in systemic and placental vasculopathy. ${ }^{13,15}$ However, other studies in psoriasis, show no significantly increased risks of birth defects or other adverse pregnancy outcomes. ${ }^{8,11-13}$ Genomic imprinting from fathers with psoriasis has been suggested to be responsible for children from fathers with psoriasis being considerably (270g) heavier than from mothers with psoriasis. ${ }^{6}$

As with increasing maternal age, the comorbidities of psoriasis are more commonly seen in those with greater disease severity and disease duration. These comorbidities include metabolic syndrome (diabetes, obesity, cardiovascular disease, hypertension), osteoporosis, depression/anxiety, alcohol and smoking. These need to be factored in when assessing maternal and fetal risks. ${ }^{12}$ In Australia, pregnant women with psoriasis are more likely to be overweight/obese, depressed, smoke in their first trimester, and are also less likely to take prenatal vitamins or supplements, than non-psoriatics. ${ }^{12}$

The baseline risk for a live born baby to have a major birth defect is $3 \%$, while the risk of a significant neuro-developmental problem, which may not become apparent until later in life, is $5 \%$ of all live births. In half of these the cause is unknown, $25 \%$ are multifactorial, $10+\%$ chromosomal, $8 \%$ single gene disorders, $3 \%$ maternal illness including infection, and only 2$3 \%$ attributable to medications and/or chemicals. ${ }^{16}$

Teratogens are environmental agents introduced during pregnancy that induce or increase the incidence of a congenital (structural) malformation. A dose-response is usually observed with a no-effect level for every agent. Inter-individual differences in susceptibility do occur, due to variation in both pharmacokinetics and pharmacogenomics of the teratogen. Timing of exposure can be critical, with risks determined by the stage of fetal development and exposure (see Table 1). Of concern is when teratogenicity occurs at therapeutic doses of medications.

Behavioural teratogens are environmental agents that interfere with maturation and development of the embryo or fetus resulting in functional impairments such as deafness, 
visual loss or neurodevelopmental problems. Examples of behavioural teratogens include alcohol and rubella. Agents such as acitretin are both teratogens and behavioural teratogens.

\section{Australian categorisation system for prescribing medicines in pregnancy}

The Australian Drug Evaluation Committee's (ADEC) categorisation system for prescribing medicines in pregnancy provides guidance in regard to the risk of drugs used in pregnancy (also used in New Zealand). It is a readily available reference (https://www.tga.gov.au/prescribing-medicines-pregnancy-database); however other sources of information for pregnancy (and lactation) can provide more valuable information for noncategory A classified medications. ADEC has limitations that can be misinterpreted, such as interpreting the categories as representing gradation of risk (e.g. Category B3 may not necessarily be safer than Category $\mathrm{C}$ ). In addition, ADEC does not provide guidance in regard to risks during the different stages of pregnancy (Table 1). Categories are often assigned on the basis of animal studies and maybe slow to change despite new evidence. ADEC does not comment on drug safety during breast-feeding. Evidence-based obstetric drug information and counselling services such as MotherSafe (www.mothersafe.org.au) and others (www.motherisk.org; www.mothertobaby.org; www.toxnet.nlm.nih.gov) are also available.

\section{Psoriasis \& pre-pregnancy counselling}

Women with chronic medical conditions, including psoriasis, who potentially require longterm medical therapy, should consider pre-pregnancy counselling. Pre-pregnancy counselling also allows the opportunity to discuss other important aspects of risk, including maternal age, family history, general health and lifestyle, including diet, weight, smoking, alcohol and illicit drugs. Pre-pregnancy counselling should include:

- Risks of underlying psoriasis, and under-treatment, to mother and baby

- Risk of specific psoriasis therapy to fetus, in relation to background risk of defects

- Alternate medication or non-pharmacological options for psoriasis

- Lowest effective dose

- Consider timed drug discontinuation during greatest at-risk period

- Contraception - early swapping of oral contraception to barrier methods

- Deferring pregnancy until optimal disease control

- Immunisation pre-pregnancy 
- Influenza vaccine should usually be offered to all women in the influenza season.

- Pertussis booster is now given to all women at 26-28 weeks of pregnancy but can also be offered to prospective child-minders such as grandparents, etc.

- Check for immunity to rubella and varicella prior to initiating immunomodulatory therapy.

- $\operatorname{MMR}$ (measles, mumps, rubella) and varicella vaccine are both live vaccines and should therefore be avoided in people on established immunosuppressive therapy.

\section{Paternal considerations (fertility and mutagenicity)}

Information to date is generally reassuring regarding mutagenic risks for men from systemic (and topical) psoriasis treatments. This includes methotrexate at immunomodulatory doses, ciclosporin, acitretin and biologic therapies (Table 2 and 3).

\section{Specific psoriasis treatments and pregnancy (Table 2 and 3)}

This section is divided into systemic therapies and topical anti-psoriasis treatments. Each drug is discussed separately, with comments regards pregnancy exposure, unplanned exposure, breast-feeding and effects on male fertility/mutagenicity. Where evidence is limited, we provide expert opinion. Most of the available evidence comes from the use of these medications for other inflammatory disorders, in particular rheumatoid arthritis and inflammatory bowel disease.

As a general recommendation, effective drugs that have been widely used for a long time are preferable to newer alternatives with less fetal safety data. This is particularly true for possible behavioural teratogens. It is, however, equally important to evaluate the risks of not treating the patient's psoriasis, as severe untreated disease may negatively impact both mother and the fetus.

The greatest teratogen risk is $1^{\text {st }}$ trimester exposure, often when the patient is unaware of being pregnant. Compliance with pregnancy prevention for teratogenic medication is unfortunately often poor. A French study reporting on a cohort of 8672 women aged 15-49 prescribed acitretin, documented 470 pregnancies (27/1000 person years). Pregnancy testing rate prior to therapy was only $4 \%$ for general practitioners, $12 \%$ for hospital dermatologists and $16 \%$ for private dermatologists. ${ }^{17}$ 
When considering stopping a drug, the half-life $\left(t^{1 / 2} / 2\right)$ should determine the timing. The recommended washout period is at least five half-lives, i.e. if the $t^{1 / 2}$ is 10 days, then stop the drug 50 days prior to conception. Exceptions are acitretin and methotrexate.

To minimize the delay in conception in patients who are established on oral contraception, consider swapping the oral contraception to a barrier method, to allow re-establishment of regular menstrual cycle. Once their menses have normalized, stop/change their disease modifying therapy for the appropriate washout period before attempting conception.

\section{Acitretin (ADEC category X)}

Acitretin is a $2^{\text {nd }}$-generation retinoid. It is a metabolite of etretinate with a $t^{1 / 2}$ of 2 days. It binds to nuclear receptors that regulate gene transcription, inducing keratinocyte differentiation and reducing epidermal hyperplasia, leading to the slowing of cell reproduction.

Fetal exposure to acitretin can result in the classic retinoid syndrome, consisting of wellcharacterized craniofacial, cardiac, thymic and CNS malformations (and neurodevelopmental problems). ${ }^{18,19}$ There have been 318 prospectively reported cases (http://www.drugs.com/pro/acitretin-capsules.html) involving pregnancies and the use of etretinate, acitretin, or both. In 238 of these cases, the conception occurred after etretinate (103 cases), acitretin (126), or both (9). Fetal outcome was unknown in approximately one-half of these cases (62 were terminated, 14 spontaneous abortions). In 118 pregnancies with known outcome, 15 were abnormal (including cases of absent hand/wrist, clubfoot, GI malformation, hypocalcemia, hypotonia, limb malformation, neonatal apnea/anemia, neonatal ichthyosis, placental disorder/death, undescended testicle, and 5 cases of premature birth).

Despite its short $t^{1} / 2$, acitretin has been detected two months after the last dose. In the presence of alcohol, acitretin can be retro-converted to etretinate ( $t^{1 / 2}-120$ days). The recommendation is therefore to discontinue acitretin two years before conception. ${ }^{20-21}$ In individuals who can follow strict alcohol abstinence during therapy, and for at least 2-months after cessation, a shorter washout period may be acceptable, but it is best to seek expert advice. ${ }^{21-23}$

Unintended exposure: Although 103 of 118 live births exposed to acitretin/etretinate were born healthy, the risk is considered very high.

Breast-feeding: Limited information indicates that maternal doses of acitretin of $0.65 \mathrm{mg} / \mathrm{kg}$ 
daily, produce low levels in milk (approximately 1\%). Because there is no published experience with acitretin during breastfeeding, opinions vary on the advisability of breastfeeding during acitretin therapy. ${ }^{24}$ Expert opinion is that low levels of acitretin are unlikely to be toxic to the neonate.

Male fertility/mutagenicity: Small amounts of acitretin are found in the semen of males, but there is no evidence of teratogenicity at conception, as the main at risk period is 4-6 weeks later. Expert opinion is that on-going exposure via semen during pregnancy is of low risk; however, barrier method of contraception post conception may be considered. Acitretin has no effect on male fertility or mutagenicity. ${ }^{25}$

\section{Apremilast (ADEC category B3)}

Apremilast is a small molecule analog of thalidomide, and acts as an immunomodulatory drug. It is a selective inhibitor of phosphodiesterase 4 (PDE4) and down-regulates expression of a number of pro-inflammatory factors including TNF $\alpha$, interleukin 17 , and interleukin $23{ }^{26}$

Although apremilast is classified as ADEC B3, it is currently contraindicated in pregnancy. Experimental animal studies do not suggest an increase in malformations with apremilast, but have shown dose related fetal loss and reduced birth weight. There is no human pregnancy outcome data, but a pregnancy registry has been established. Given its narrow toxic/therapeutic ratio and very limited human data, it should be stopped at least two days before conception ( $\mathrm{t}^{1} / 2$ -9 hours).

Unintended exposure: There is no human pregnancy outcome data, but a pregnancy registry has been established.

Breast-feeding: No human data currently available. Apremilast was detected in the milk of lactating mice at levels approximately 1.5-times that of simultaneously collected blood plasma samples. Given the limited information currently available, apremilast is currently best avoided during lactation.

Male fertility/mutagenicity: No human data currently available. Apremilast was negative in the in vitro bacterial mutagenicity test (Ames assay), the in vitro chromosomal aberration assay, and the in vivo mouse micronucleus assay. ${ }^{27}$ 


\section{Ciclosporin (ADEC category C)}

Ciclosporin is an immunosuppressive drug that blocks the transcription of cytokine genes in activated $\mathrm{T}$ cells. It inhibits calcineurin, which regulates nuclear translocation and subsequent activation of transcription factors. The $t^{1} / 2$ is 8 hours.

Ciclosporin has been associated with an increased risk of low birth weight and prematurity in pregnant organ transplant recipients ${ }^{28}$ but there does not appear to be an increased risk of congenital anomalies. ${ }^{29}$ It may therefore be a reasonable option in pregnant women with psoriasis. Close monitoring of blood pressure and renal function, and monitoring for urinary tract infections is recommended. Nephrotoxicity has been identified in the offspring of experimental animals exposed prenatally to ciclosporin, but not in the small numbers of human children studied. A small amount (10-15\%) of the maternal dose of ciclosporin crosses the placenta. $^{29-30}$

Unintended exposure: seek appropriate specialist advice but the current data of exposure to ciclosporin during pregnancy is relatively reassuring (see above).

Breast-feeding: Ciclosporin is excreted in breast milk though most infants studied have not had detectable ciclosporin levels. If concerned, ciclosporin levels can be measured in the neonate. ${ }^{31}$

Male fertility/mutagenicity: there is no evidence that ciclosporin affects male fertility or has a mutagenic effect.

Methotrexate (ADEC category D)

Low-dose methotrexate $(<0.4 \mathrm{mg} / \mathrm{kg} /$ week $)$ is an immunomodulator. ${ }^{32}$ Methotrexate's mechanism of action is anti-inflammatory, inhibiting 5-aminoimidazole-4-carboxamide ribonucleotide transformylase (AICAR), rather than as a tetrahydofolate reductase inhibitor. ${ }^{33}$ The $\mathrm{t}^{1 / 2} \mathbf{2}$ is $3-10$ hours.

Methotrexate is teratogenic, or lethal (abortifacient), to embryos of all animal species tested. Fetal risks are dependent on maternal dose and timing of exposure. Review of human methotrexate-exposed pregnancies, suggest that the maternal dose necessary to induce defects is $>10 \mathrm{mg}$ per week, and the postulated critical period is between 6-8 weeks post conception. Exposure outside the proposed critical period (6-8 weeks post conception) appears not to raise 
baseline risk significantly. Rate of miscarriage is increased in methotrexate-exposed women and the longer the period of exposure post conception, the higher the risk for miscarriage. ${ }^{34}$ The outcome of first trimester exposures to low dose methotrexate $(7.5 \mathrm{mg} / \mathrm{week})$ in eight patients with rheumatic disease were all favourable (no malformations or apparent intellectual defects). ${ }^{35}$ A more recent study of 28 cases of first trimester exposure to low dose methotrexate $(<15 \mathrm{mg} / \mathrm{wk}$, mean $10.5 \mathrm{mg} / \mathrm{wk})$ observed 4 spontaneous abortions, 5 therapeutic abortions and 19 live births with only one child (exposed until week 8.5) with minor anomalies. ${ }^{36}$ In contrast a single case report of an infant with multiple congenital anomalies born to a mother with juvenile rheumatoid arthritis on weekly low-dose methotrexate during the first trimester had abnormalities found consistent with aminopterin syndrome. ${ }^{37}$ Higher (chemotherapy/abortifacient) doses of methotrexate $(>0.4 \mathrm{~kg} / \mathrm{kg} /$ week) have been associated with prenatal growth deformities (aminopterin syndrome), including growth retardation, large fontanelles, craniosynostosis, ocular hypertelorism, micrognathia, limb abnormalities and developmental delay. ${ }^{38}$

Although the $t^{1 / 2}$ of methotrexate is 3-10 hours, and is undetectable in serum within 24 hours, it is common to stop 12 weeks before conception as methotrexate may be stored in both kidneys (weeks) and liver (months). The weekly folate supplementation should be increased to daily. ${ }^{39}$ It may be possible to re-introduce low-dose methotrexate (e.g. 7.5-10 mg/week) in the later stages of the $2^{\text {nd }}$ trimester, but little safety data exists. ${ }^{34-36}$ Concern has been expressed over possible effects on neurodevelopment, although this has not been reported with high dose chemotherapy doses. ${ }^{40}$

Unintended exposure: Seek specialist advice to discuss whether or not to continue the pregnancy.

Breast-feeding: at chemotherapy doses, breast-feeding should be avoided during, and for one week after, the last dose. With immunomodulatory doses $(<0.4 \mathrm{mg} / \mathrm{kg} / \mathrm{week})$, levels found in breast milk are very low (breast milk to plasma ratio $=0.08: 1) .{ }^{41}$ Opinion is divided over the significance of this, but it is likely to be of low neonatal risk; a precautionary approach would be to monitor the infant's complete blood count at one and three months of age.

Male fertility/mutagenicity: Methotrexate may have slight negative effects on sperm count (i.e. fertility), but not on mutagenicity/teratogenicity. ${ }^{42-43}$ A study of 113 pregnancies with paternal low-dose methotrexate treatment was reassuring and did not support the need for a 3-month 
washout period (i.e. there is no evidence that paternal methotrexate needs to be discontinued).

\section{Prednisone/Prednisolone (ADEC category A)}

Prednisone/prednisolone is a synthetic glucocorticoid, with minimal mineralocorticoid activity. It binds to glucocorticoid receptors inducing gene expression and/or inhibition, leading to the synthesis of anti-inflammatory proteins. Systemic steroids are not commonly used in the treatment of psoriasis, but may be of value in specific situations. The $t^{1 / 2}$ is 60 minutes.

There is a long history of systemic corticosteroid use for the management of many inflammatory medical disorders during pregnancy. Systemic glucocorticoids have been associated with low birth weight, intrauterine growth restriction, and other fetal abnormalities. Cleft lip with or without cleft palate has been reported following first trimester use. ${ }^{44-47}$ Recently concerns have been expressed regarding $3^{\text {rd }}$ trimester/neonatal use of systemic corticosteroids and neurodevelopmental delay, but data is limited. Despite this, systemic steroids are still recommended for the treatment of pustular psoriasis of pregnancy, which most commonly occurs in the later stages of pregnancy. ${ }^{48}$ As cortisone and prednisone are more readily inactivated by the placenta then dexamethasone and betamethasone, these may be preferred for the treatment of pustular psoriasis of pregnancy.

Women taking longer term, higher dose, corticosteroids should be counseled over the risks of osteoporosis; consider a baseline bone density assessment prior to a planned pregnancy. Use of corticosteroids during pregnancy is associated with increased risks of hypertension and diabetes, both of which occur more frequently in pregnancy.

Unintended exposure: No specific action needed.

Breast-feeding: Low levels of systemic steroids are found in milk, but the clinical effects are thought to be minimal. Peak milk levels of prednisone were $102 \mathrm{mcg} / \mathrm{L}$ after a $20 \mathrm{mg}$ dose. ${ }^{49}$ As peak milk steroid levels occur 2 hours after a dose, when practicable, wait 4 hours after ingestion of systemic steroids before breast-feeding. ${ }^{50-51}$ Large doses of corticosteroids in the $3^{\text {rd }}$ trimester may reduce milk production.

Male fertility/mutagenicity: No concerns; systemic steroids may improve fertility in men with anti-sperm antibodies. No evidence of mutagenicity/teratogenicity. 


\section{Biologicals (adalimumab, certolizumab, etanercept, ixekizumab, infliximab, secukinumab, ustekinumab)}

There is growing data with regard to the safety of biologic therapy in human pregnancy, but it remains limited. ${ }^{52-53}$ There are three main considerations in using biologics during pregnancy:

- Teratogenicity and malformations (early pregnancy)

- Fetal and neonate immunosuppression and immune development (last trimester to 6months of age)

- Increased maternal immunosuppression (particularly later pregnancy)

Most, but not all, monoclonal antibodies behave like maternal antibodies; the Fc moiety is involved in actively transporting antibodies across the placenta beginning in the $2^{\text {nd }}$ trimester and rapidly increases during the $3^{\text {rd }}$ trimester. This can result in therapeutic levels of monoclonal antibodies in the fetus, particularly during later stages of pregnancy. These may then persist for several months in the newborn.

The monoclonal biologics do not all cross the placenta equally. IgG1 (adalimumab, infliximab, secukinumab, ustekinumab) and IgG4 (ixekizumab) monoclonal antibodies are likely to cross the placenta to a similar extent, with preferential transport of IgG1 over IgG4 ${ }^{54-55}$ Infliximab and adalimumab levels were higher in infants at birth than in the maternal circulation (median $160 \%$ and $153 \%$ of maternal levels), and were detectable for up to 6-months after birth. Certolizumab, a pegolated monoclonal antibodies lacking an Fc moiety, crosses the placenta by passive transfer, with median levels of $3.9 \%$ of mothers' blood levels. ${ }^{56}$ Etanercept, a receptorantibody fusion protein, which includes the Fc domain of human $\mathrm{IgG1}$, is present at much lower levels in neonatal cord blood (2.5-3.3\% of maternal levels), and rapidly declines in the weeks after birth, even with breast-feeding. ${ }^{57-58}$

Caution needs to be taken with live vaccines (MMR, polio and rotavirus), following $3^{\text {rd }}$ trimester fetal exposure to anti-TNF- $\alpha$ biologics,. An otherwise healthy $4 \frac{1}{2} 2$ month old baby died from disseminated Bacillus Calmetter-Guerin (BCG) following BCG vaccination at 3 months of age. The mother had received infliximab for Crohn's disease throughout pregnancy. ${ }^{59}$ The current recommendation is to delay live vaccines until 6-12 months of age. Alternatively, some experts recommend stopping the biologics after the $2^{\text {nd }}$ trimester to reduce this risk. Data for anti IL-12/23 is not yet available, so the precautionary approach would be to 
follow similar restrictions.

Inactivated vaccines should be given at standard schedules as per the Australian Immunisation Handbook $^{60}$

(http://www.immunise.health.gov.au/internet/immunise/publishing.nsf/Content/Handbook10$\underline{\text { home) }}$ or New Zealand Immunisation Handbook ${ }^{61}$ (http://immunisation.book.health.govt.nz/). Note that the immune response may be suboptimal and "additional doses" may be required.

Pregnancy is a state of relative immunosuppression and therefore there is a theoretical risk of serious and opportunistic maternal infections, particularly in the $3^{\text {rd }}$ trimester. Of special concern is the increased risk of intracellular infections, such as Listeria moncytogenes. ${ }^{62-64}$ Guidance on safe food consumption during pregnancy should be reinforced (https://www.mpi.govt.nz/document-vault/3675). ${ }^{65}$

\section{Adalimumab (ADEC category C)}

Adalimumab is a fully human monoclonal antibody $\left(\operatorname{IgG}_{1}\right)$ that binds TNF- $\alpha$, thereby reducing inflammation. The $t^{1} / 2$ of adalimumab is 14 days; should washout be desired, adalimumab would need to be stopped 70 days (10 weeks) prior to conception.

Animal studies have revealed no teratogenic, embryotoxic or fetotoxic effects. In rheumatoid arthritis there were no significant differences for any adverse pregnancy outcomes in 60 exposed pregnancies, compared to 71 disease control patients and 148 healthy women. ${ }^{66}$

Unintended exposure: No action needed, as currently there is no data to suggest teratogenicity, embryotoxicity or fetotoxicity.

Breast-feeding: Adalimumab is a large protein molecule (molecular weight $\approx 148,000 \mathrm{kDa}$ ), so the amount in milk is very low; in addition adalimumab is likely to be destroyed in the infant's gastrointestinal tract. Preliminary, but limited data, is reassuring. General recommendations however, recommend caution in premature and infants $<1$ month of age.

Male fertility/mutagenicity: Studies of anti-TNF- $\alpha$ have generally found improvement in sperm motility and vitality. There is no increased risk for congenital abnormalities associated with paternal use of anti-TNF therapy. ${ }^{67}$ 


\section{Certolizumab (ADEC category C)}

Certolizumab is a recombinant, humanized antibody Fab' fragment, with specificity for human TNF- $\alpha$. It lacks an Fc moiety. It selectively neutralizes membrane-associated and soluble human TNF- $\alpha$. The $t^{1 / 2}$ is 14 days; washout would be 70 days ( 10 weeks) before conception.

Animal studies have failed to reveal fetal harm from certolizumab. Data from 253 exposed human pregnancies has not raised concerns of adverse pregnancy outcomes: $75.5 \%$ pregnancies resulted in live births, $14.6 \%$ had spontaneous miscarriages, and $9.9 \%$ elected to terminate their pregnancy. In the live birth group, 3 infants had congenital malformations: 1 vesicoureteric reflux, 1 congenital morbus Hirschsprung and club feet, and 1 high aortic arch with aberrant left subclavian vein. ${ }^{68}$ As there is less placental transfer of certolizumab, it is considered low risk and compatible with use during conception and $1^{\text {st }}$ and $2^{\text {nd }}$ trimesters. ${ }^{69}$ There is an early signal of increased maternal infections. ${ }^{64}$ As with all biologics, there needs to be awareness of possible neonatal immunosuppression when used in the $3^{\text {rd }}$ trimester and delay use of live vaccinations until 6 months of age. Note: certolizumab is not currently funded for psoriasis in either Australia/New Zealand.

Breast-feeding: Preliminary data indicate that certolizumab is not excreted into breast milk, which would be expected because of its high molecular weight. Absorption is unlikely because of destruction in the infant's gastrointestinal tract. ${ }^{56}$ In a study of 102 breast feeding women on anti-TNF agent there were no reported complications in the infant, their growth or development. ${ }^{70}$ Although the manufacturer recommends that breast-feeding be discontinued during therapy, expert opinion considers it safe during breast-feeding. General recommendations however, recommend caution in premature and infants $<1$ month of age.

Unintended exposure: no action is necessary as certolizumab is considered low risk during conception, $1^{\text {st }}$ and $2^{\text {nd }}$ trimesters

Male fertility/mutagenicity: no treatment effects of certolizumab were seen on semen quality in 20 healthy male subjects. ${ }^{71}$

\section{Etanercept (ADEC category D)}

Etanercept is a dimeric fusion protein consisting of the extracellular ligand-binding portion of the human TNF receptor linked to the Fc portion of human IgG1. It binds specifically to 
soluble and cell surface tumour TNF, blocking its interaction with cell surface TNF receptors. The $t^{1} / 2$ is 3 days; washout would be 15 days before conception.

In a report of 138 pregnancies exposed to etanercept there were 6 spontaneous miscarriages and 2 terminations (unspecified heart defect and Turner syndrome), 130 live births (11 had minor birth defects with no specific pattern of malformation). ${ }^{69}$ Based on the limited available data, etanercept does not appear to increase the risk for major congenital malformations above the baseline risk in the general population, despite the ADEC categorisation (D).

Unintended exposure: no action is necessary as etanercept is considered low risk during conception, $1^{\text {st }}$ and $2^{\text {nd }}$ trimesters.

Breastfeeding: Etanercept is minimally excreted into breast milk and poorly absorbed by the infant, which would be expected because of its high molecular weight of approximately $150,000 \mathrm{kDa} .^{52,72}$

Male fertility/mutagenicity: Studies of anti-TNF- $\alpha$ have generally found improvement in sperm motility and vitality in the groups treated with anti-TNF therapy. There is no evidence of increased risk for congenital abnormalities associated with paternal use of anti-TNF therapy. ${ }^{67}$

Infliximab (ADEC category $\mathrm{C}$ )

Infliximab is a chimeric IgG1 $\kappa$ monoclonal antibody to human TNF- $\alpha$. It binds specifically to soluble and transmembrane forms of human TNF- $\alpha$. The $t \frac{1}{2}$ is 10 days, so if it was desired to cease infliximab, do so 50 days (7 weeks) prior to conception.

Based on over 200 exposed pregnancies, infliximab does not appear to increase the risk of major congenital malformations above the baseline risk in the general population and is considered to be low risk and compatible with use during conception and pregnancy in at least the $1^{\text {st }}$ and $2^{\text {nd }}$ trimesters. $^{69}$

Unintended exposure: no action is necessary as infliximab is considered low risk during conception, $1^{\text {st }}$ and $2^{\text {nd }}$ trimesters. 
Breast-feeding: Infliximab is usually not detectable in breast milk. In one study, minute concentrations were found, but not high enough to be of concern for systemic immunosuppression. $^{73}$

Male fertility/mutagenicity: Studies of anti-TNF- $\alpha$ have generally found improvement in sperm motility and vitality in the groups treated with anti-TNF therapy. There is no evidence of increased risk for miscarriages or congenital abnormalities associated with paternal use of antiTNF therapy.

Ixekizumab (ADEC category - not categorised yet)

Ixekizumab is a humanized monoclonal antibody (IgG4) that binds to interleukin (IL)-17A. IL17 is important for 1) host defense against extracellular bacteria and fungi, 2) neutrophil homeostasis, and 3) chronic pathogenic inflammation. The $t^{1} / 2$ is 13 days, so ixekizumab washout would be 65 days ( 9 weeks) prior to conception.

There is limited data on the use of ixekizumab in pregnant women. In developmental toxicity studies, ixekizumab was shown to cross the placenta and was present in the blood of offspring for up to 6 months of age, but animal studies do not, as yet, indicate direct or indirect harmful effects with respect to pregnancy, embryonic/fetal development, parturition or post-natal development. As there is no human data, ixekizumab is currently contraindicated during pregnancy.

Unintended exposure: no human data. Seek specialist counseling.

Breast-feeding: Ixekizumab is excreted at low levels in the milk of cynomolgus monkeys, but it is unknown whether it is excreted in human milk, or absorbed systemically after ingestion. It is a large protein molecule (molecular weight - 146,000 kDa), so absorption is unlikely after the first few weeks postpartum. Due to lack of human data, expert opinion currently recommends ixekizumab should not be used whilst breast-feeding.

Male fertility/mutagenicity: No human data. No effects on reproductive organs, menstrual cycles or sperm were observed in sexually mature cynomolgus monkey. The precautionary approach would recommend that ixekizumab be stopped 9 weeks before conception, although expert opinion considers the risk is low. 


\section{Secukinumab (ADEC category $C)$}

Secukinumab is a human IgG1 $\kappa$ monoclonal antibody that selectively binds to interleukin-17A inhibiting its pro-inflammatory effects. As the $t^{1 / 2}$ is 27 days, secukinumab washout would be 135 days ( 19 weeks) before conception.

No human data yet. In developmental toxicity studies conducted with monkeys, there was no harm to the fetuses of pregnant mothers given secukinumab weekly during the period of organogenesis. The precautionary approach would be to avoid secukinumab during pregnancy.

Unintended exposure: No human data. Seek specialist advice.

Breast-feeding: No human data. Secukinumab is a large protein molecule (molecular weight $151,000 \mathrm{kDa}$ ), so absorption is unlikely after the first few weeks postpartum. Expert opinion currently recommends secukinumab should not be used whilst breast-feeding, as there is no human data.

Male fertility/mutagenicity: No signs of teratogenicity, embryo toxicity, or effects on fertility were observed in the reproductive toxicology studies. The precautionary approach would recommend that secukinumab be stopped 19 weeks prior to conception, although expert opinion considers the risk is low.

\section{Ustekinumab (ADEC category B1)}

Ustekinumab is an IgG1 monoclonal antibody binding to the p40 subunit of IL-12 and IL-23. As a consequence, ustekinumab interrupts the abnormal activation of signaling and cytokine cascades that underlie the pathology of psoriasis. As the $t \frac{1}{2}$ is 21 days, the washout period for ustekinumab is 105 days (15 weeks).

The data on anti-IL-12/23 monoclonal antibodies is too immature to make any recommendation. ${ }^{74-75}$ The current precautionary approach would be to avoid ustekinumab during pregnancy.

Unintended exposure: No human data. Seek specialist advice. 
Breast-feeding: No human data. As ustekinumab has a molecular weight of 149,000 kDa, the amount in milk is likely to be very low and absorption is unlikely because of destruction in the infant's gastrointestinal tract. ${ }^{76}$

Male fertility/mutagenicity: there are no studies regarding the safety of ustekinumab in reproductive males. The precautionary approach would recommend that ustekinumab be stopped 15 weeks prior to conception, although expert opinion considers the risk low.

Phototherapy-UVB/nbUVB (ADEC category none)

Phototherapy with broad-band (290-320 nm) ultraviolet B (UVB) and narrow-band UVB (311$312 \mathrm{~nm}$ ) appears to be safe during pregnancy and breast feeding. ${ }^{77}$ However, there may be depletion of maternal folate, so folic acid supplementation is strongly recommended. Note: UVB may aggravate melasma/chloasma.

Unintended exposure: No concerns.

Breast-feeding: No concerns. It is advised to keep sunscreens away from the breast and instead rely on clothing to protect from the sun.

Male fertility/mutagenicity: No concerns.

Phototherapy-PUVA (ADEC category C)

The safety of systemic PUVA with psoralens is unknown; mutagenic potential has been shown in rat studies. In a study of 107 patients, limited cases of premature labor and fetal abnormalities were reported. ${ }^{78}$ A previous study was more reassuring. ${ }^{79}$ Expert opinion, however, recommends avoiding PUVA during pregnancy.

Unintended exposure: No concerns.

Breast-feeding: No data. Expert opinion is to delay breast-feeding for 5 hours after last dose.

Male fertility/mutagenicity: Very limited data. Some experts suggest topical PUVA limited to small areas is safe. ${ }^{77}$ Expert opinion considers that any risk is low.

\section{Topical anti-psoriasis therapies}


Most topical psoriasis treatments can be used during pregnancy, possibly with the exceptions of anthralin (dithranol) and retinoids (e.g. tazarotene). However, there is generally a dearth of data to make any evidenced-based recommendations.

There are no major concerns using any topical therapy whilst breast-feeding, although it is best to wipe off the breast prior to breast-feeding as passive transfer might occur through skin-toskin contact. Water-miscible cream or gel products are preferred, as ointments may expose the infant to high levels of mineral paraffins via licking. ${ }^{80}$

There are no implications of paternal use of topical preparations used for the treatment of psoriasis, with respect to male fertility or mutagenicity.

\section{Anthralin/dithranol (ADEC category B2)}

Currently not recommended during pregnancy due to lack of human and animal data. However, there is no evidence that it is unsafe. Advice is to stop 4-weeks prior to conception and avoid during pregnancy. Expert opinion is that this is likely to be safe if used sparingly (e.g. < 30 $\mathrm{gm} /$ week), but the low efficacy may not warrant the unknown risk.

Unintended exposure: Seek specialist advice, but it is unlikely that any action would be indicated.

Breast-feeding: No particular risk, but avoid application near the breast as likely to be irritant to neonatal skin.

\section{Coal tar (ADEC category none)}

Animal studies and case reports raise safety concerns. In a retrospective study of 103 pregnancies: there were 59 pregnancies without use of coal tar (19\% spontaneous abortion, $5 \%$ congenital disorder), 21 pregnancies uncertain use of coal tar (5\% spontaneous stillbirth, $5 \%$ congenital disorders), and 23 pregnancies with definite use of coal tar (26\% spontaneous abortion, $4 \%$ congenital disorder). Expert opinion is that lower concentrations, such as 5\% liquor picis carbonis, as opposed to crude coal tar, are safe, and can be used in small amounts for short periods of time in the $2^{\text {nd }}$ and $3^{\text {rd }}$ trimesters ( $<10 \mathrm{gm} /$ day for 3-4 weeks). Probably best avoided in the $1^{\text {st }}$ trimester. $^{81}$ 
Unintended exposure: No action needed.

Breast-feeding: No specific concerns. May be irritant on neonatal skin.

Calcipotriol (ADEC category C)

Systemic absorption may occur. Animal studies show increased incidence of skeletal abnormalities, incomplete ossification of pubic bones and forelimb phalanges of fetuses following oral calcipotriol. No data from humans. Maternal vitamin D toxicity may have teratogenic risks. Expert advice is to keep doses to less than 25-50 gm/week for 3-4 weeks.

Unintended exposure: No action needed.

Breast-feeding: No specific concerns. Maybe irritant to neonatal skin.

Corticosteroids - mild (ADEC category A to B3)

It is interesting that systemic steroids are categorised as ADEC - A, but topical corticosteroids, which would have significantly lower systemic levels, are classified B3. A long history of use indicates they are safe if used in appropriate doses, duration and amount. Potent topical corticosteroids are absorbed and can have systemic effects. Animal data and human data show dose dependent risks of placental insufficiency and low birth weight. ${ }^{82-83}$ Expert opinion is to limit mild potency topical corticosteroids (e.g. 1\% hydrocortisone cream) to less than 100 $\mathrm{gm} /$ week, potent topical corticosteroids (e.g. betamethasone valerate cream) to $<50 \mathrm{gm} / \mathrm{week}$, and super potent topical corticosteroids (e.g. clobetasol propionate) to $<30 \mathrm{gm} /$ week.

Unintended exposure: No action needed.

Breast-feeding: No specific concerns.

Salicylic acid (ADEC category none)

There is limited data on its use in pregnancy. A moderate amount (9-25\%) of applied salicylic acid may be absorbed systemically and has been shown to have effects both early and late in pregnancy. ${ }^{84}$ To limit potential systemic safety concerns, higher concentrations $(>3 \%)$, large amounts (e.g. >20 gm/day) or use under occlusion, should be avoided. 
Unintended exposure: No action needed.

Breast-feeding: Salicylic acid is excreted in breast milk. As a consequence of Reye's syndrome, expert advice is to avoid applying to the breasts, keep doses of salicylic acid low (e.g. 1-2\%), and use small amounts (e.g. $<20$ gm/day) for short periods.

Tacrolimus (topical - not classified, systemic - ADEC category C)

There is almost no data on topical use of tacrolimus in pregnancy. Oral tacrolimus is associated with prematurity and low birth weight, ${ }^{85-86}$ but systemic absorption is minimal, particularly if applied to small areas, for short duration (e.g. $<5 \mathrm{gm} /$ day for 2-3 weeks).

Unintended exposure: No action needed.

Breast-feeding: No specific concerns.

Tazarotene (ADEC category D)

Tazarotene is rapidly converted after skin application to the active metabolite tazarotenic acid. Pharmacokinetic studies show that less than $6 \%$ of the administered dose of tazarotene (or tazarotenic acid) is absorbed, even when applied to psoriatic skin. Tazarotene and its metabolites are not lipophilic. A small risk cannot be excluded but considered unlikely. Expert advice is to discontinue topical tazarotene four weeks prior to conception, and avoid during pregnancy. It is possible that they could be used in the $3^{\text {rd }}$ trimester, but the low efficacy of this medication may not warrant the unknown risk. ${ }^{87}$

Unintended exposure: Seek specialist advice, but it is unlikely that any action would be indicated.

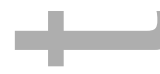

Breast-feeding: No particular risk.

\section{Summary}

The treatment of psoriasis around pregnancy is fraught with difficulties. The manifestations of abnormal development include: death (abortion), congenital malformation, growth retardation and neurobehavioural defects. As a general recommendation, anti-psoriatic drugs that have been used extensively for years are preferable to newer alternatives, which have limited fetal 
and maternal safety data. This is particularly true for possible behavioural teratogens. It is, however, equally important to evaluate the risks of not treating the patient's psoriasis, as severe untreated disease may negatively impact both mother and the fetus.

As with increasing maternal age, the comorbidities of psoriasis are more commonly seen in those with greater disease severity and disease duration. Where risks are not modifiable, pregnancy-counselling aims to ensure that prospective parents are told of the potential risks so they can then make appropriately informed decisions. Should unintended exposure to potential teratogens occur, counselling becomes imperative before a decision to either continue or terminate the pregnancy is made.

\section{References}

1. 1. Finer LB, Zolna MR. Unintended pregnancy in the United States: incidence and disparities, 2006. Contraception. 2011;84:478-85.

2. 2. Mazza D, Harrison $\mathrm{C}$, Taft $\mathrm{A}$ et al. Unplanned pregnancy and emergency contraception in Australia: unsolved dilemmas. Aust N Z J Public Health. 2014;38:110-1.

3. Green AC. Australian Aborigines and psoriasis. Australas J Dermatol. 1984;25:18-24.

4. Henseler T, Christophers E. Psoriasis of early and late onset: characterization of two types of psoriasis vulgaris. J Am Acad Dermatol. 1985;13:450-6.

5. Lowes MA, Bowcock AM, Krueger JG. Pathogenesis and therapy of psoriasis. Nature 2007;445:866-73.

6. Nair RP, Stuart PE, Nistor I et al. Sequence and haplotype analysis supports HLA-C as the psoriasis susceptibility 1 gene. Am J Hum Genet. 2006;78:827-51.

7. Nair RP, Duffin KC, Helms C et al. Genome-wide scan reveals association of psoriasis with IL-23 and NF-kB pathways. Nat Genet. 2009;41:199-204.

8. 3. Gladman DDAK, Schachter RK, Mervart H. HLA antigens in psoriatic arthritis. J Rheumatol. 1986;13:586-92.

9. 4. Valdimarsson H. The genetic basis of psoriasis. Clin Dermatol. 2007;25:563-67.

10. 5. Rahman PEJ. Genetic epidemiology of psoriasis and psoriatic arthritis. Ann Rheum Dis. 2005;64 (Suppl 2):ii37-9.

11. 6. Traupe H, van Gurp PJ, Happle R et al. Psoriasis vulgaris, fetal growth, and genomic imprinting. Am J Med Genet. 1992;42:649-54. 
12. 7. Swanbeck G, Inerot A, Martinsson T et al. Genetic counselling in psoriasis: empirical data on psoriasis among first-degree relatives of 3095 psoriatic probands. Br J Dermatol. 1997;137:939-42.

13. Setty ARCG, Choi HK. Obesity, waist circumference, weight change, and the risk of psoriasis in women: Nurses' Health Study II. Arch Intern Med. 2007;167:1670-5.

14. Setty ARCG, Choi HK. Smoking and the risk of psoriasis in women: Nurses' Health Study II. Am J Med. 2007;120:953-9.

15. Naldi LCL, Linder D, Belloni Fortina A et al. Cigarette smoking, body mass index, and stressful life events as risk factors for psoriasis: results from an Italian case-control study. $\mathrm{J}$ Invest Dermatol. 2005;125:61-7.

16. Koebnick C, Black MH, Smith $\mathrm{N}$ et al. The association of psoriasis and elevated blood lipids in overweight and obese children. J Pediatr. 2011:159: 577-83.

17. 8. Boyd AS, Morris LF, Phillips CM et al. Psoriasis and pregnancy: hormone and immune system interaction. Int J Dermatol. 1996;35:169-72.

18. 9. Murase JE, Chan KK, Garite TJ et al. Hormonal effect on psoriasis in pregnancy and post partum. Arch Dermatol. 2005;141:601-6.

19. 10. Tauscher AE, Fleischer AB Jr, Phelps KC, Feldman SR. Psoriasis and pregnancy. J Cutan Med Surg. 2002;6:561-70.

20. 11. Horn EJ, Chambers CD, Menter A, Kimball AB. International Psoriasis Council. Pregnancy outcomes in psoriasis: why do we know so little? J Am Acad Dermatol. 2009;61:e5-8.

21. 12. Bandoli G, Johnson DL, Jones KL et al. Potentially modifiable risk factors for adverse pregnancy outcomes in women with psoriasis. Br J Dermatol. 2010;163:334-9.

22. 13. Yang YW, Chen CS, Chen YH et al. Psoriasis and pregnancy outcomes: a nationwide population-based study. J Am Acad Dermatol. 2011;64:71-7.

23. 14. Ryan C, Sadlier M, De Vol E et al. Genital psoriasis is associated with significant impairment in quality of life and sexual functioning. J Am Acad Dermatol. 2015;72:97883.

24. 15. Cohen-Barak E, Nachum Z, Rozenman D et al. Pregnancy outcomes in women with moderate-to-severe psoriasis. J Eur Acad Dermatol Venereol. 2011;25:1041-7.

25. 16. Kalter H, Warkany J. Medical progress. Congenital malformations: etiologic factors and their role in prevention (first of two parts). N Engl J Med. 1983;308:424-31. 
26. Matok I, Gorodischer R, Koren G et al. Exposure to folic acid antagonists during the first trimester of pregnancy and the risk of major malformations. Br J Clin Pharmacol. 2009;68:956-62.

27. Chatzi L, Papadopoulou E, Koutra K et al. Effect of high doses of folic acid supplementation in early pregnancy on child neurodevelopment at 18 months of age: the mother-child cohort 'Rhea' study in Crete, Greece. Public Health Nutr. 2012;15:1728-36.

28. 17. Raguideau F, Mezzarobba M, Zureik M et al. Compliance with pregnancy prevention plan recommendations in 8672 French women of childbearing potential exposed to acitretin. Pharmacoepidemiol Drug Saf. 2015;24:526-33.

29. 18. De Die-Smulders CE, Sturkenboom MC, Veraart J et al. Severe limb defects and craniofacial abnormalities in fetus conceived during acitretine therapy. Teratology. 1995;52:215-9.

30. 19. Barbero P, Lotersztein V, Bronberg R, Perez M, Alba L. Acitretin embryopathy: a case report. Birth Defects Res A Clin Mol Teratol. 2004;70:831-3.

31. 20. Maier H, Honigsmann H. Concentration of etretinate in plasma and subcutaneous fat after long-term acitretin. Lancet. 1996;348:1107.

32. 21. Gronhoj LF, Steinkjer B, Jakobsen P et al. Acitretin is converted to etretinate only during concomitant alcohol intake. Br J Deramtol. 2000;143:1164-9

33. 22. Geiger J-M, Baudin M, Saurat J-H. Teratogenic risk with etretinate and acitretin treatment. Deramtology. 1994;189:109-16.

34. 23. Maradit H, Geiger J-M. Potential risk of birth defects after acitretin discontinuation. Dermatology. 1999;198:3-4.

35. 24. Rollman O, Pihl-Lundin I. Acitretin excretion into human breast milk. Acta Derm Venereol. 1990;70:487-90.

36. 25. Geiger JM. Walker M. Is there a reproductive safety risk in male patients treated with acitretin (neotigason/soriatane)? Dermatology. 2002:205:105-7.

37. 26. Schafer P. Apremilast mechanism of action and application to psoriasis and psoriatic arthritis. Biochem Pharmacol. 2012;83:1583-90.

38. 27. Otezla Package Insert. Celgene Corporation; Summit, NJ. 2014.

39. 28. Lamarque V, Leleu MF, Monka C, Krupp P. Analysis of 629 pregnancy outcomes in renal transplant recipients with Sandimmune. Transplant Proc. 1997;29:2480.

40. 29. Bar OB, Hackman R, Einarson T, Koren G. Pregnancy outcome after cyclosporine therapy during pregnancy: a meta-analysis. Transplantation. 2001;71:1051-5. 
41. 30. Kura MM, Surjushe AU. Generalized pustular psoriasis of pregnancy treated with oral cyclosporine. Indian J Dermatol Venereol Leprol. 2006;72:458-9.

42. 31. Thiru Y, Bateman DN, Coulthard MG. Successful breast-feeding while mother was taking cyclosporine. BMJ 1997; 315:463.

43. 32. Rademaker M, Gupta M, Andrews M et al. The Australasian Psoriasis Collaboration view on Methotrexate for psoriasis in the Australasian setting, Austral J Dermatol. 2016 Jul 12. [Epub ahead of print]

44. 33. Cronstein B. How does methotrexate suppress inflammation? Clin Exp Rheumatol. 2010;28(Suppl. 61):S21-3.

45. 34. Feldkamp M, Carey JC. Clinical teratology counselling and consultation case report: low dose methotrexate exposure in the early weeks of pregnancy. Teratology. 1993;47:5339.

46. 35. Kozlowski RD, Steinbrunner JV, MacKenzie AH et al. Outcome of first-trimester exposure to low-dose methotrexate in eight patients with rheumatic disease. Am J Med. 1990;88:589-92.

47. 36. Lewden B, Vial T, Elefant E et al. Low dose methotrexate in the first trimester of pregnancy: results of a French collaborative study. J Rheumatol. 2004;31:2360-5.

48. 37. Buckley LM, Bullaboy CA, Leichtman L, Marquez M. Multiple congenital anomalies associated with weekly low-dose methotrexate treatment of the mother. Arthritis Rheum. 1997;40:971-3.

49. 38. Svirsky R, Rozovski U, Vaknin Z et al. The safety of conception occurring shortly after methotrexate treatment of ectopic pregnancy. Reprod Toxicol. 2009;27:85-7.

50. 39. Braga A, Maesta I, Michelin OC et al. Maternal and perinatal outcomes of first pregnancy after chemotherapy for gestational trophoblastic neoplasia in Brazilian women. Gynecol Oncol. 2009;112:568-71.

51. 40. Kaleita TA, Reaman GH, MacLean WE, Sather HN, Whitt JK. Neurodevelopmental outcome of infants with acute lymphoblastic leukemia: a Children's Cancer Group report. Cancer. 1999;85:1859-65.

52. 41. Johns DG, Rutherford LD, Leighton PC, Vogel CL. Secretion of methotrexate into human milk. Am J Obstet Gynecol. 1972; 112:978-80.

53. 42. Grunnet E, Nyfors A, Hansen KB. Studies on human semen in topical corticosteroidtreated and in methotrexate-treated psoriatics. Dermatologica. 1977:154:78-87. 
54. 43. Weber-Schoendorfer C, Hoeltzenbein M, Wacker E et al. No evidence for an increased risk of adverse pregnancy outcome after paternal low-dose methotrexate: an observational cohort study. Rheumatology. 2014;53:757-63.

55. 44. Pradat P, Robert-Gnasia E, Di Tanna GL, Rosano A, Lisi A, Mastroiacovo P. Contributors to the MADRE Database. First trimester exposure to corticosteroids and oral clefts. Birth Defects Res A Clin Mol Teratol. 2003;67:968-70.

56. 45. Rodriguez-Pinilla E, Martinez-Frias ML. Corticosteroids during pregnancy and oral clefts: a case-control study. Teratology. 1988;58:2-5.

57. 46. Carmichael SL, Shaw GM. Maternal corticosteroid use and risk of selected congenital anomalies. Am J Med Genet. 1999;86:242-4.

58. 47. Wapner RJ, Sorokin Y, Mele L et al. Long-term outcomes after repeat doses of antenatal cortieosteroids. N Engl J Med. 2007;357:1190-8.

59. 48. Lee SH, Hunt MJ, Barnetson RS. Pustular psoriasis of pregnancy. Australas J Dermatol. 1995;36:199-200.

60. 49. Sagraves R, Kaiser D, Sharpe GL. Prednisone and prednisolone concentrations in the milk of a lactating mother. Drug Intell Clin Pharm. 1981;15:484.

61. 50. Greenberger PA, Odeh YK, Frederiksen MC, Atkinson AJ Jr. Pharmacokinetics of prednisolone transfer to breast milk. Clin Pharmacol Ther. 1993;53:324-8.

62. 51. McKenzie SA, Selley JA, Agnew JE. Secretion of prednisolone into breast milk. Arch Dis Child. 1975;50:894-6.

63. 52. Hyrich KL, Verstappen SM. Biologic therapies and pregnancy: The story so far. Rheumatology (Oxford). 2014;53:1377-85.

64. 53. Ali YM, Kuriya B, Orozco C et al. Can tumor necrosis factor inhibitors be safely used in pregnancy? J Rheumatol. 2010;37:9-17

65. 54. Garty BZ, Ludomirsky A, Danon YL et al. Placental transfer of immunoglobulin G subclasses. Clin Diagn Lab Immunol. 1994;1: 667-9.

66. 55. Irani V, Guy AJ, Andrew D et al. Molecular properties of human IgG subclasses and their implications for designing therapeutic monoclonal antibodies against infectious diseases. Molecular Immunology. 2015;67:171-82.

67. 56. Mahadevan U, Wolf DC, Dubinsky M et al. Placental transfer of anti-tumor necrosis factor agents in pregnant patients with inflammatory bowel disease. Clin Gastroenterol Hepatol. 2013;11:286-92. 
68. 57. Vermeersch P, De Beeck K O, Lauwerys BR et al. Etanercept during pregnancy and lactation in a patient with rheumatoid arthritis: drug levels in maternal serum, cord blood, brest mild and the infant's serum. Ann Rheum Dis. 2009:68:1793-4.

69. 58. Berthelsen BG, Fjeldsoe-Nielsen H, Nielsen CT, Hellmuth E. Etanercept concentrations in maternal serum, umbilical cord serum, breast mild and child serum during breastfeeding. Rheumatology. 2010;49:2225-7.

70. 59. Cheent K, Nolan J, Shariq S et al. Case report: fatal case of disseminated BCG infection in an infant born to a mother taking infliximab for Crohn's disease. J Crohns Colitis 2010;4:603-5.

71. 60. Department of Health. The Australian Immunisation Handbook 10th edition (updated March 2016). Canberra. Department of Health. http://www.immunise.health.gov.au/internet/immunise/publishing.nsf/Content/Handbook1 0-home (accessed 15.07.2016)

72. 61. Ministry of Health. 2016. Immunisation Handbook 2014 (2nd edn). Wellington: Ministry of Health. http://immunisation.book.health.govt.nz/ (accessed 15.07.2016)

73. 62. Davies R, Dixon WG, Watson KD et al. Influence of anti-TNF patient warning regarding avoidance of high risk foods on rates of listeria and salmonella infections in the UK. Ann Rheum Dis. 2013;72:461-2.

74. 63. Dixon WG, Watson K, Lunt M et al. Rates of serious infection, including site-specific and bacterial intracellular infection, in rheumatoid arthritis patients receiving anti-tumor necrosis factor therapy: results from the British Society for Rheumatology Biologics Register. Arthritis Rheum 2006;54:2368-76.

75. 64. Förger F, Zbinden A, Villiger PM. Certolizumab treatment during late pregnancy in patients with rheumatic diseases: low drug levels in cord blood but possible risk for maternal infections. A case series of 13 patients. Joint Bone Spine. 2016;83:341-3.

76. 65. Food safety in Pregnancy. Ministry for Primary Industries. Wellington, New Zealand https://www.mpi.govt.nz/document-vault/3675 (accessed 15.07.2016)

77. 66. Chambers C, Johnson DL, Yunjun J et al. Pregnancy Outcome in Women Treated with Adalimumab for the Treatment of Rheumatoid Arthritis: The OTIS Autoimmune Diseases in Pregnancy Project. Arthritis Rheum. 2012;64 (Suppl 10):2466.

78. 67. Puchner R, Danninger K, Puchner A et al. Impact of TNF-blocking agents on male sperm characteristics and pregnancy outcomes in fathers exposed to TNF-blocking agents at time of conception. Clin Exp Rheumatol. 2012; 30:765-7. 
79. 68. Wolf DC, Förger F, Cush JJ et al. Retrospective analysis of certolizumab pegol use during pregnancy: update of impact on birth outcomes. Arthritis Rheum. 2013;65 (Suppl 10):S187-S188.

80. 69. Mahadevan U, Cucchiara S, Hyams JS et al. The London Position Statement of the World Congress of Gastroenterology on Biological Therapy for IBD with the European Crohn's and Colitis Organisation: pregnancy and pediatrics. Am J Gastroenterol 2011;106:214-23.

81. 70. Mahadevan U, Martin CF, Sandler RS et al. PIANO: a 1000 patient prospective registry of pregnancy outcomes in women with IBD exposed to immunomodulators and biologic therapy. Gastroenterology. 2012;142(Suppl 1):S149.

82. 71. Yiu ZZ, Griffiths CE, Warren RB. Safety of biological therapies for psoriasis: effects on reproductive potential and outcomes in male and female patients. Br J Dermatol. 2014;171:485-91.

83. 72. Ostensen M, Eigenmann GO. Etanercept in breast milk. J Rheumatol. 2004;31:1017.

84. 73. Ben-Horin S, Yavzori M, Kopylov U et al. Detection of infliximab in breast milk of nursing mothers with inflammatory bowel disease. J Crohns Colitis. 2011;5:555-8.

85. 74. Sheeran C, Nicolopoulos J. Pregnancy outcomes of two patients exposed to ustekinumab in the first trimester. Australas J Dermatol. 2014;55:235-6.

86. 75. Rocha K, Piccinin MC, Kalache LF, Reichert-Faria A, Silva de Castro CC. Pregnancy during ustekinumab treatment for severe psoriasis. Dermatology. 2015;231:103-4.

87. 76. Götestam Skorpen C, Hoeltzenbein M, Tincani A et al. The EULAR points to consider for use of antirheumatic drugs before pregnancy, and during pregnancy and lactation. Ann Rheum Dis. 2016;75:795-810.

88. 77. Lam J, Polifka JE, Dohil MA. Safety of dermatologic drugs used in pregnant patients with psoriasis and other inflammatory skin diseases. J Am Acad Dermatol. 2008;59:295315.

89. 78. Stern RS, Lange R. Outcomes of pregnancies among women and partners of men with a history of exposure to methoxsalen photochemotherapy (PUVA) for the treatment of psoriasis. Arch Dermatol. 1997;127:347-50.

90. 79. Gunnarskog JG, Kallen AJ, Lindelof BG, Sigurgeirsson B. Psoralen photochemotherapy (PUVA) and pregnancy. Arch Dermatol. 1993;129:320-3.

91. 80. Noti A, Grob K, Biedermann M et al. Exposure of babies to C(15)-C(45) mineral paraffins from human milk and breast salves. Regul Toxicol Pharmacol. 2003;38:317-25. 
92. 81. Franssen ME, van der Wilt GJ, de Jong PC, Bos RP, Arnold WP. A retrospective study of the teratogenicity of dermatological coal tar products. Acta Derm Venereol. 1999;79:390-1.

93. 82. Chi C-C, Kirtschig G, Aberer W et al. Evidence-based (S3) guideline on topical corticosteroids in pregnancy. Br J Dermatol. 2011;165:943-52.

94. 83. Chi CC, Wang SH, Kirtschig G, Wojnarowska F. Systematic review of the safety of topical corticosteroids in pregnancy. J Am Acad Dermatol. 2010;62:694-705.

95. 84. Martinez-Frias ML, Rodriguez-Pinilla E, Prieto L. Prenatal exposure to salicylates and gastroschisis: a case-control study. Teratology. 1997;56:241-3.

96. 85. Jain AB, Reyes J, Marcos A et al. Pregnancy after liver transplantation with tacrolimus immunosuppression: a single center's experience update at 13 years. Transplantation. 2003;76:827-32.

97. 86. Kainz A, Harabacz I, Cowlrick IS, Gadgil SD, Hagiwara D. Review of the course and outcome of 100 pregnancies in 84 women treated with tacrolimus. Transplantation. 2000;70:1718-21.

98. 87. Menter A. Pharmacokinetics and safety of tazarotene. J Am Acad Dermatol. 2000;43(2 Pt3):S31-5.

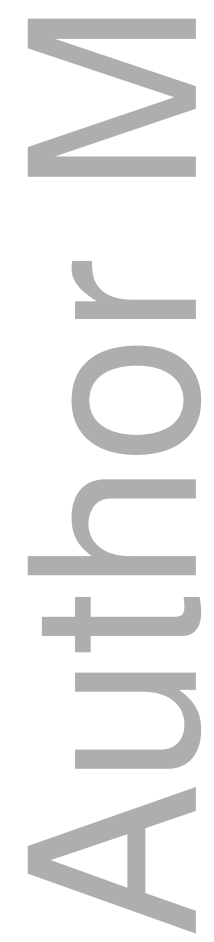


Table 1: Timing of fetal exposure can be critical to risk.

\begin{tabular}{|l|l|l|}
\hline All-or-none period & $\begin{array}{l}\text { Pre-implantation: } \\
\text { week 0-2 after } \\
\text { conception }\end{array}$ & $\begin{array}{l}\text { Few malformations originate during this time because } \\
\text { injuries to the embryo at this stage are likely to result } \\
\text { in death or in repair and recovery }\end{array}$ \\
\hline Embryonic period & $\begin{array}{l}\text { Organogenesis: } \\
\text { week 2-9 after } \\
\text { conception }\end{array}$ & $\begin{array}{l}\text { Exposures can lead to major structural abnormalities } \\
\text { and is the time of greatest susceptibility to teratogens. } \\
\text { These include neural tube defects, cardiac defects and } \\
\text { orofacial clefting }\end{array}$ \\
\hline Fetal period & Week 9-36 & $\begin{array}{l}\text { Can result in functional abnormalities. An example is } \\
\text { of impaired renal function by NSAIDs reducing fetal } \\
\text { urine and amniotic fluid production that results in } \\
\text { oligohydramnios, fetal joint contractures and and } \\
\text { pulmonary hypoplasia }\end{array}$ \\
\hline
\end{tabular}

This article is protected by copyright. All rights reserved 
Table 2: Summary of recommendation by individual systemic agent.

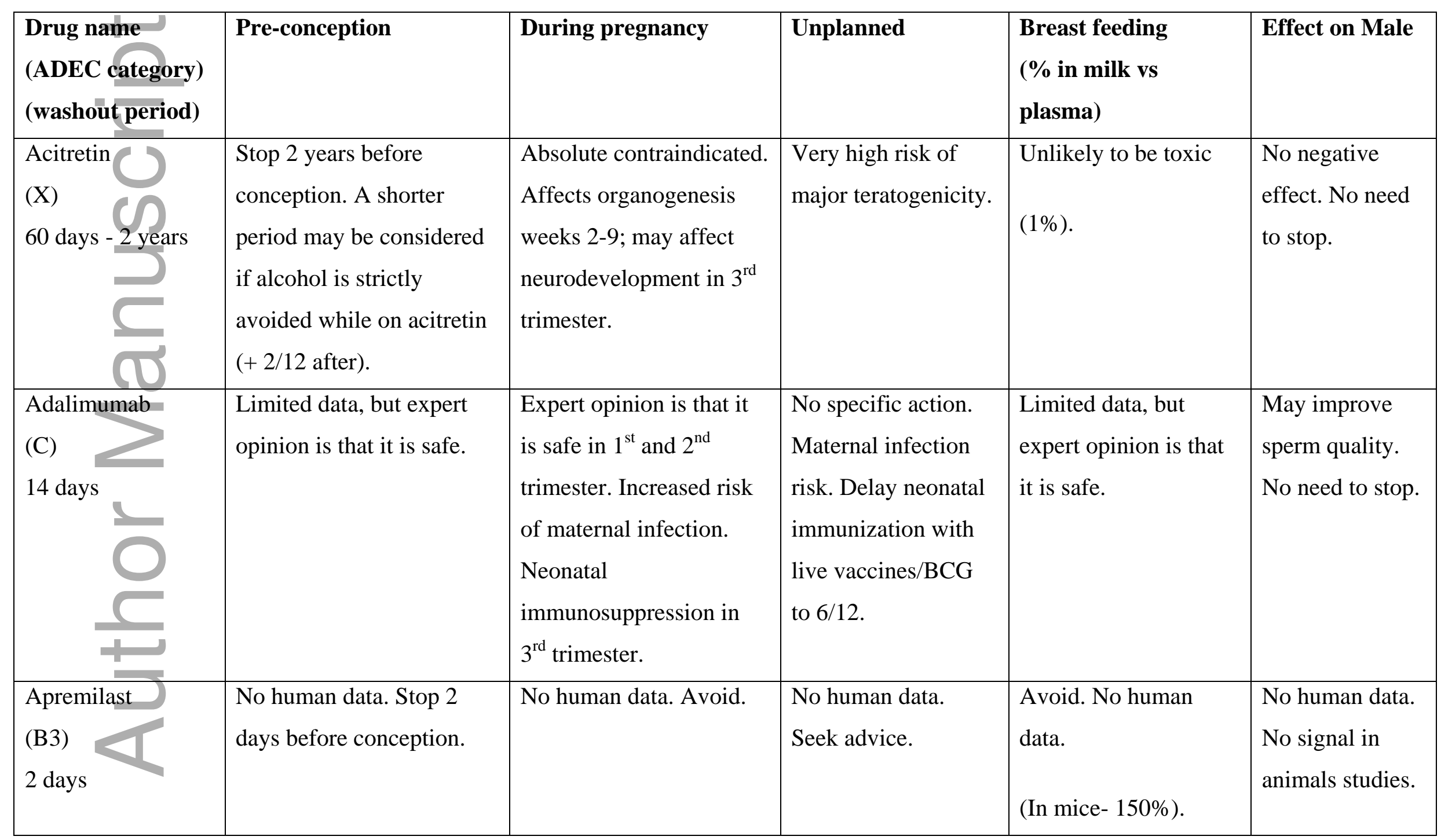

This article is protected by copyright. All rights reserved 


\begin{tabular}{|c|c|c|c|c|c|}
\hline $\begin{array}{l}\text { Certalizumab } \\
\text { (C) } \\
70 \text { days }\end{array}$ & $\begin{array}{l}\text { Limited data, but expert } \\
\text { opinion is that it is safe. }\end{array}$ & $\begin{array}{l}\text { Minimal placental } \\
\text { transfer. Expert opinion } \\
\text { is that it is safe in } 1^{\text {st }} \text { and } \\
2^{\text {nd }} \text { trimester. Increased } \\
\text { risk of maternal } \\
\text { infection. Neonatal } \\
\text { immunosuppression in } \\
3^{\text {rd }} \text { trimester. }\end{array}$ & $\begin{array}{l}\text { No specific action. } \\
\text { Maternal infection } \\
\text { risk. Delay neonatal } \\
\text { immunization with } \\
\text { live vaccines/BCG } \\
\text { to } 6 / 12 \text {. }\end{array}$ & $\begin{array}{l}\text { Limited data, but } \\
\text { expert opinion is that } \\
\text { it is safe. } \\
\text { (very little). }\end{array}$ & $\begin{array}{l}\text { May improve } \\
\text { sperm quality. } \\
\text { No need to stop. }\end{array}$ \\
\hline $\begin{array}{l}\text { Cyclosporin (C) } \\
1 \frac{1}{2} 2 \text {-2days }\end{array}$ & $\begin{array}{l}\text { Consider stopping } 2 \text { days } \\
\text { prior to conception }\end{array}$ & $\begin{array}{l}\text { Low birth weight and } \\
\text { prematurity. Increased } \\
\text { risk of maternal } \\
\text { infection. Recommend } \\
\text { attendance at high-risk } \\
\text { obstetric clinic. }\end{array}$ & $\begin{array}{l}\text { Seek advice, but } \\
\text { likely no action. } \\
\text { Recommend } \\
\text { attendance at high- } \\
\text { risk obstetric clinic }\end{array}$ & $\begin{array}{l}\text { Expert opinion is that } \\
\text { it is safe. } \\
\text { (low levels). }\end{array}$ & $\begin{array}{l}\text { No effect. No } \\
\text { need to stop. }\end{array}$ \\
\hline $\begin{array}{l}\text { Etanercep } \\
\text { (D) } \\
15 \text { days }\end{array}$ & $\begin{array}{l}\text { Limited data, but expert } \\
\text { opinion is that it is safe. }\end{array}$ & $\begin{array}{l}\text { Expert opinion is that it } \\
\text { is safe in } 1^{\text {st }} \text { and } 2^{\text {nd }} \\
\text { trimester. Increased risk } \\
\text { of maternal infection. } \\
\text { Neonatal } \\
\text { immunosuppression in } \\
3^{\text {rd }} \text { trimester. }\end{array}$ & $\begin{array}{l}\text { Maternal infection } \\
\text { risk. Delay neonatal } \\
\text { immunization with } \\
\text { live vaccines/BCG } \\
\text { to } 6 / 12 \text {. }\end{array}$ & $\begin{array}{l}\text { Limited data, but } \\
\text { expert opinion is that } \\
\text { it is safe. } \\
\text { (very little). }\end{array}$ & $\begin{array}{l}\text { May improve } \\
\text { sperm quality. } \\
\text { No need to stop. }\end{array}$ \\
\hline Infliximab & Limited data, but expert & Expert opinion is that it & Maternal infection & Limited data, but & May improve \\
\hline
\end{tabular}

This article is protected by copyright. All rights reserved 


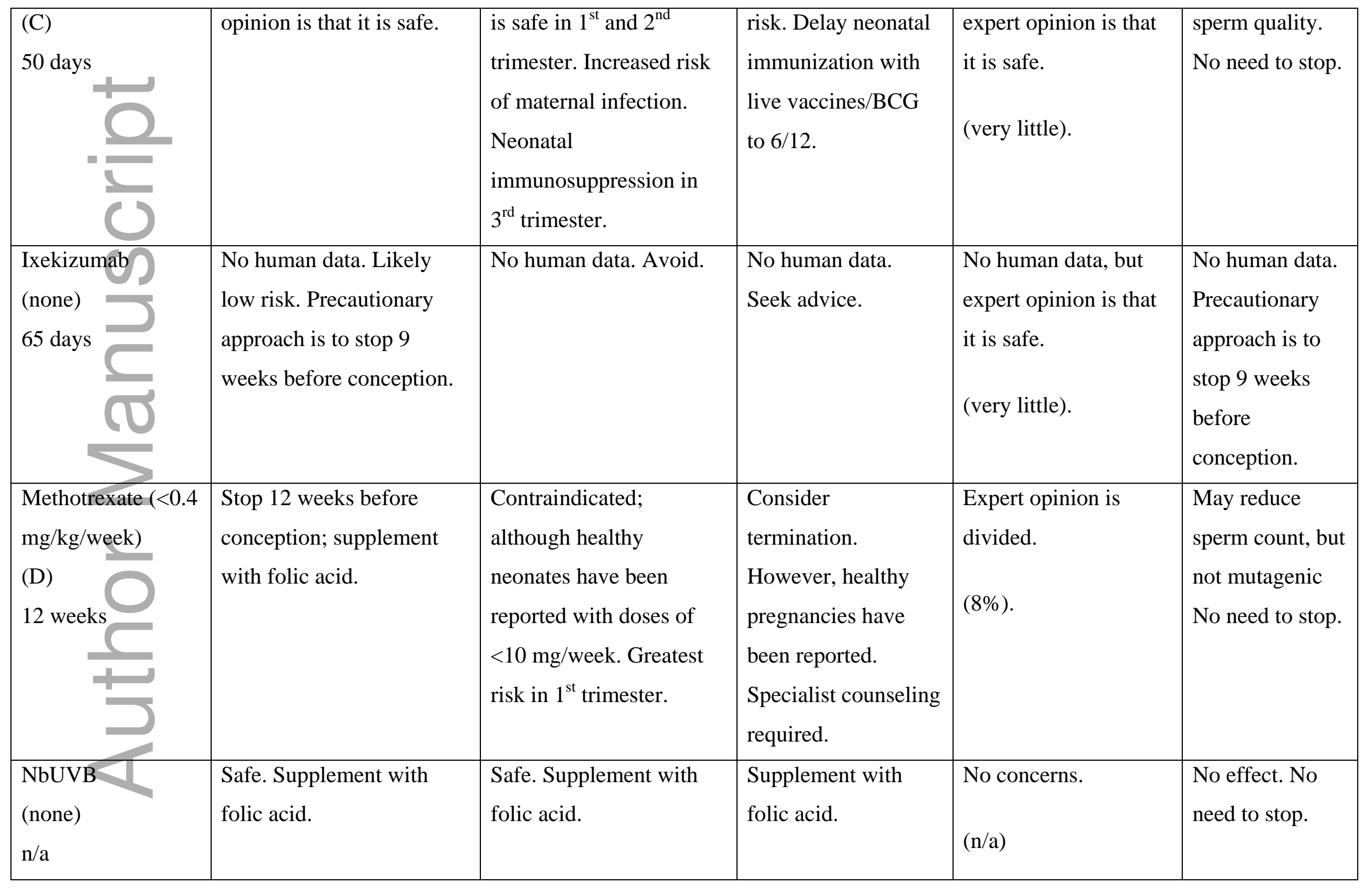

This article is protected by copyright. All rights reserved 


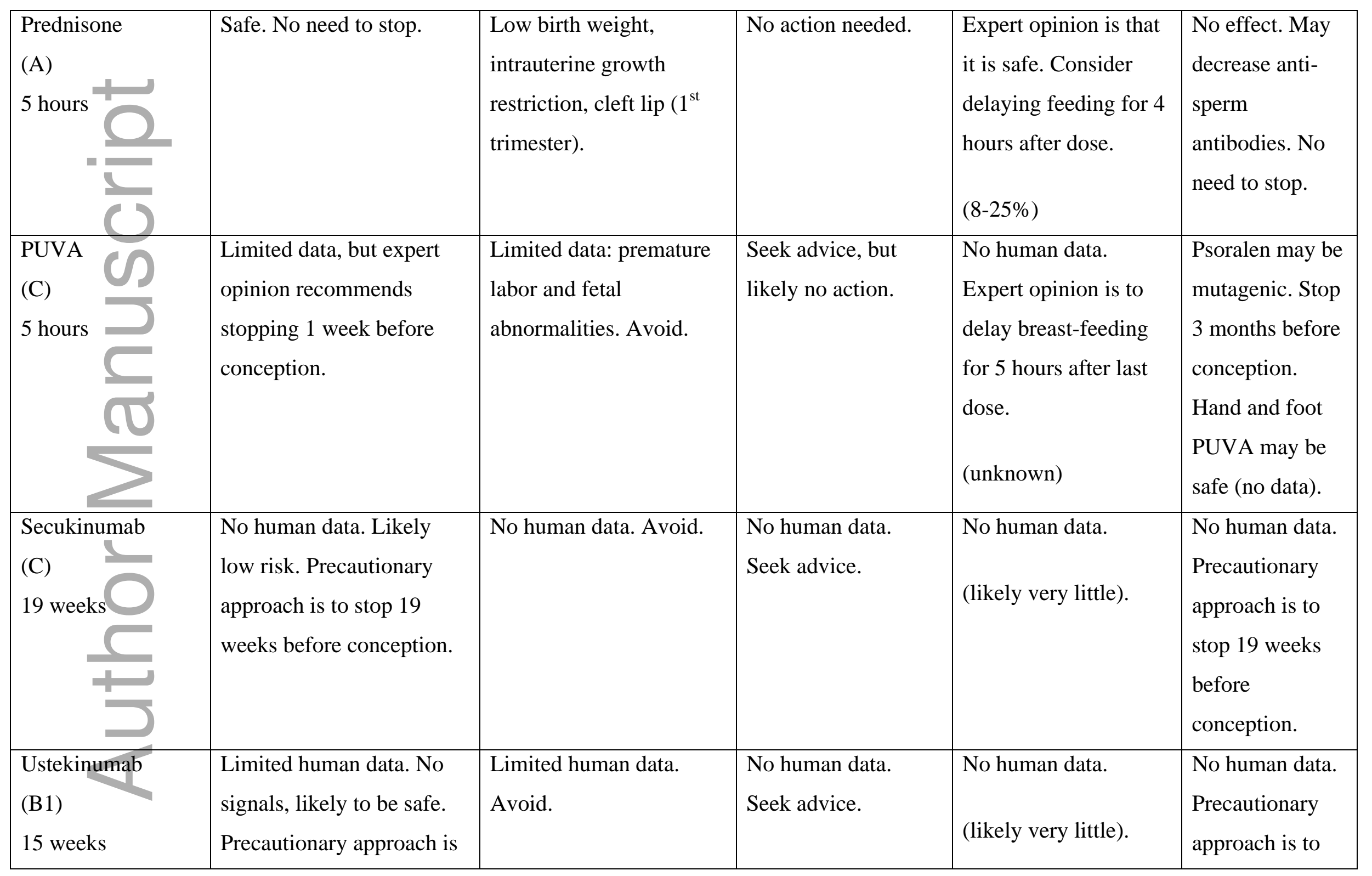

This article is protected by copyright. All rights reserved 


\begin{tabular}{|l|l|l|l|l|l|}
\hline & $\begin{array}{l}\text { to stop 15 weeks before } \\
\text { conception. }\end{array}$ & & & $\begin{array}{l}\text { stop 15 weeks } \\
\text { before } \\
\text { conception. }\end{array}$ \\
\hline
\end{tabular}

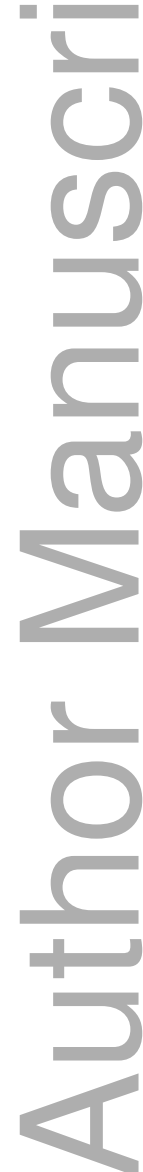

This article is protected by copyright. All rights reserved 
Table 3: Summary of recommendation by individual topical agent

\begin{tabular}{|c|c|c|c|}
\hline $\begin{array}{l}\text { Drug } \\
\text { (ADEC category) }\end{array}$ & Pre-conception & During pregnancy & $\begin{array}{l}\text { Unplanned } \\
\text { exposure }\end{array}$ \\
\hline $\begin{array}{l}\text { Anthralin/Dithranol } \\
\text { (B2) }\end{array}$ & $\begin{array}{l}\text { No human data. Expert } \\
\text { opinion - stop } 4 \text { weeks } \\
\text { before conception. }\end{array}$ & $\begin{array}{l}\text { Avoid. Expert opinion } \\
\text { is that it is safe, but } \\
\text { low efficacy. }\end{array}$ & $\begin{array}{l}\text { Seek specialist } \\
\text { advice. Likely no } \\
\text { action. }\end{array}$ \\
\hline $\begin{array}{l}\text { Calcipotriol } \\
\text { (C) }\end{array}$ & $\begin{array}{l}\text { Limited data. No signal } \\
\text { of concern. }\end{array}$ & $\begin{array}{l}\text { Limited data. } \\
\text { Systemic use } \\
\text { associated with } \\
\text { skeletal abnormalities. } \\
\text { Expert opinion: use < } \\
25-50 \text { gm/week for 3- } \\
4 \text { weeks. }\end{array}$ & $\begin{array}{l}\text { No action } \\
\text { needed. }\end{array}$ \\
\hline $\begin{array}{l}\text { Coal Tar } \\
\text { (no ADEC categ }\end{array}$ & $\begin{array}{l}\text { Limited data. No signal } \\
\text { of concern. }\end{array}$ & $\begin{array}{l}\text { Limited data. Avoid in } \\
1^{\text {st }} \text { trimester. Expert } \\
\text { opinion: use }<5 \% \\
\text { liquor picis carbonis, } \\
<10 \mathrm{gm} / \text { day, for } 3-4 \\
\text { weeks of time in } 2^{\text {nd }} \\
\text { and } 3^{\text {rd }} \text { trimester. }\end{array}$ & $\begin{array}{l}\text { No action } \\
\text { needed. }\end{array}$ \\
\hline $\begin{array}{l}\text { Corticosteroids - weak } \\
\text { (e.g. hydrocortisone) } \\
\text { B3 }\end{array}$ & No concern. & $\begin{array}{l}\text { No concern. Expert } \\
\text { opinion: use < } \\
100 \mathrm{gm} / \text { week. }\end{array}$ & $\begin{array}{l}\text { No action } \\
\text { needed. }\end{array}$ \\
\hline $\begin{array}{l}\text { Corticosteroids - } \\
\text { potent (e.g. } \\
\text { betamethasone } \\
\text { valerate) } \\
\text { B3 }\end{array}$ & $\begin{array}{l}\text { Limited controlled data } \\
\text { in human pregnancy. } \\
\text { Expert opinion is that it } \\
\text { is safe. }\end{array}$ & $\begin{array}{l}\text { Long history of use } \\
\text { indicates they are safe. } \\
\text { Expert opinion: use < } \\
\text { 50gm/week. }\end{array}$ & $\begin{array}{l}\text { No action } \\
\text { needed. }\end{array}$ \\
\hline $\begin{array}{l}\text { Corticosteroids - } \\
\text { super-potent (e.g. } \\
\text { clobetasol propionate) } \\
\text { B3 }\end{array}$ & $\begin{array}{l}\text { Limited controlled data } \\
\text { in human pregnancy. } \\
\text { Expert opinion is that it } \\
\text { is safe. }\end{array}$ & $\begin{array}{l}\text { Long history of use } \\
\text { indicates they are safe. } \\
\text { Expert opinion: use < } \\
30 \mathrm{gm} / \text { week. }\end{array}$ & $\begin{array}{l}\text { No action } \\
\text { needed. }\end{array}$ \\
\hline
\end{tabular}




\begin{tabular}{|c|c|c|c|}
\hline $\begin{array}{l}\text { Moisturisers } \\
\text { (no ADEC category) }\end{array}$ & $\begin{array}{l}\text { Limited data but } \\
\text { extensive usage } \\
\text { indicates it is safe. }\end{array}$ & Safe. & $\begin{array}{l}\text { No action } \\
\text { needed. }\end{array}$ \\
\hline $\begin{array}{l}\text { Salicylic acid } \\
\text { (no ADEC category) }\end{array}$ & $\begin{array}{l}\text { No data. Expert } \\
\text { opinion: keep } \\
\text { concentration }<3 \% \text {, } \\
\text { and use }<100 \mathrm{gm} / \text { week }\end{array}$ & $\begin{array}{l}\text { Keep concentration } \\
\text { below } 3 \% \text {, and less } \\
\text { than } 100 \mathrm{gm} / \text { week }\end{array}$ & $\begin{array}{l}\text { No action } \\
\text { needed. }\end{array}$ \\
\hline $\begin{array}{l}\text { Tacrolimus } \\
(\mathrm{C}-\text { oral })\end{array}$ & $\begin{array}{l}\text { Limited data. Expert } \\
\text { opinion considers it } \\
\text { safe. }\end{array}$ & $\begin{array}{l}\text { Oral use associated } \\
\text { with low birth weight } \\
\text { and prematurity, but } \\
\text { systemic absorption } \\
\text { minimal. Expert } \\
\text { opinion: use <5 } \\
\text { gm/day, for } 2-3 \\
\text { weeks. }\end{array}$ & $\begin{array}{l}\text { No action } \\
\text { needed. }\end{array}$ \\
\hline $\begin{array}{l}\text { Tazarotene } \\
\text { (D) }\end{array}$ & $\begin{array}{l}\text { Limited data. Expert } \\
\text { opinion: stop } 4 \text { weeks } \\
\text { before conception. }\end{array}$ & $\begin{array}{l}\text { Avoid. Limited } \\
\text { human data. } \\
\text { Theoretical risk as it is } \\
\text { a retinoid. }\end{array}$ & $\begin{array}{l}\text { Seek advice. } \\
\text { Likely no action. }\end{array}$ \\
\hline
\end{tabular}




\section{University Library}

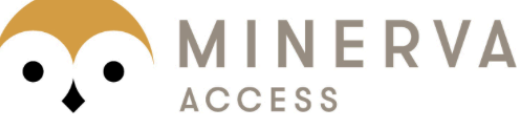

A gateway to Melbourne's research publications

Minerva Access is the Institutional Repository of The University of Melbourne

Author/s:

Rademaker, M;Agnew, K;Andrews, M;Armour, K;Baker, C;Foley, P;Frew, J;Gebauer, K;Gupta, M;Kennedy, D;Marshman, G;Sullivan, J

Title:

Psoriasis in those planning a family, pregnant or breast-feeding. The Australasian Psoriasis Collaboration

Date:

2018-05-01

Citation:

Rademaker, M., Agnew, K., Andrews, M., Armour, K., Baker, C., Foley, P., Frew, J., Gebauer, K., Gupta, M., Kennedy, D., Marshman, G. \& Sullivan, J. (2018). Psoriasis in those planning a family, pregnant or breast-feeding. The Australasian Psoriasis Collaboration. AUSTRALASIAN JOURNAL OF DERMATOLOGY, 59 (2), pp.86-100. https://doi.org/10.1111/ ajd.12641.

Persistent Link:

http://hdl.handle.net/11343/292928 